\title{
TOTAL PHENOLIC COMPOUNDS AND ANTIOXIDANT ACTIVITY OF Stachys turcomanica
}

\author{
COMPOSTOS FENÓLICOS TOTAIS E ATIVIDADE ANTIOXIDANTE DA Stachys \\ turcomanica
}

\author{
Khashaiar NAMVAR ${ }^{1}$; Esmaeil Ataye SALEHI ${ }^{1}$; Naeim MOKHTARIAN ${ }^{1}$ \\ 1. Department of Food science and technology, Quchan Branch, Islamic Azad University, Quchan, Iran. eatayesalehi@yahoo.com
}

\begin{abstract}
The subject of free radicals and their effects on biological systems is an important problem in Medicine. Antioxidants can protect biological systems against free radicals. In this study, the effect of methanol ratio $(0$, $20,50,80$, and 100\%) in water on extraction yield of Total phenolic (TP) compounds and antioxidant activity (AA) of Stachys turcomanica extract were evaluated. The amount of TP compounds were determined using Folin-Ciocalteu reagent, and AA measured by 2, 2-diphenyl-1-picrylhydrazyl (DPPH), ferric reducing antioxidant power (FRAP) and betacaroten linoleic acid methods. The results showed extraction of phenolic compounds and their AA were affected by solvent combinations. In addition, there was a good correlation between TP content and AA of Stachys turcomanica extracts. Finally the methanol: water (80:20) was good solvent in extracting of phenolic compounds with highest AA.
\end{abstract}

KEYWORDS: Antioxidant activity. Phenolic compounds. Stachys turcomanica.

\section{INTRODUCTION}

The genus of Stachys with 300 species is in Lamiaceae family and it was found in Mediterranean area and Iran (TUNDIS 2014). In Iran, this genus has 34 species (MOZAFFARIAN, 1996). The plants in this genus have anticancer, antipyretic, antitoxic, anti-anxiety, anti-proliferative, anti-inflammatory, antibacterial and antioxidant activities (GHAHRAMAN 1998, HAJHASHEMI 2007, MORTEZA-SEMNANI 2006, RABBANI 2005, RABBANI 2003, AYDIN 2006, DIGRAK 2001). Some species of this genus are used for treating abdominal pains and they used as disinfectant, antispasmodic and anti-fever agents (GRUENWALD et al., 2000). Phytochemical analysis demonstrated presence of mono terpenes, sesquiterpenes [AGHAEI 2013, DELAZAR 2011], flavonoids (EL-ANSARI et al., 1995) and phenylethanoid glycosides (MIYASE et al., 1996; NISHIMURA et al., 1991) in this genus. In Iran, the aerial parts of Stachys genus are used for infection, rheumatic and inflammatory disease (MALEKI et al., 2001). One of the Iranian species is Stachys turcomanica (RECHINGER; HEDGE, 1982; MOZAFFARIAN, 1996). Medicinal plants are known for their antioxidant compounds and they are less toxic than synthetic antioxidants (BURDA; OLESZEK, 2001; HOLLMAN et al., 1996). Some conditions such as kind of solvent, temperature, concentration and extraction time have effects on the extraction of phenolic compounds (LIYANAPATTHIRANA; SHAHIDI, 2004). The types of solvent and extracted compounds determine the antioxidant activity of the extract, Therefore the selection of solvent is important (NOBRE et al., 2005). Antioxidant activity in plants has been associated with phenolic compounds (THABREW et al., 1998) such as carotenoids, vitamins, phenols and flavonoids (CAO et al., 1997; VELIOGLU et al., 1998). In this work, we report the best solvent in the extraction of antioxidant compounds from Stachys turcomanica. Various methods were performed for evaluation of antioxidant activity, and in this study three methods such as FRAP, DPPH and beta-caroten linoleic acid were used. In addition, total phenolic content was determined.

\section{MATERIAL AND METHODS}

\section{Plant material}

The aerial parts of Stachys turcomanica were collected in Jun 2014 from the North Khorasan Province Mountains of Iran. The plant was identified by Natural Products \& Medicinal Plants Research Center, North Khorasan University of Medical Sciences (Iran).

\section{Preparation of plant extracts \\ About $150 \mathrm{~g}$ of plant was macerated in methanol $100 \%$, methanol $80 \%$, methanol $50 \%$, methanol $20 \%$ and water at room temperature for 48 $\mathrm{h}$ separately. The solvent was in contact with plant for $48 \mathrm{~h}$ and then the solvent was removed under vacuum at $40{ }^{\circ} \mathrm{C}$ to give the crude extract (PRACHAYASITTIKUL et al., 2008).}




\section{Total phenolic Determination}

The total phenolic content in the different extracts of Stachys turcomanica was assessed using Folin-Ciocalteu reagent and gallic acid as a standard. Gallic acid solutions were prepared with concentrations of $0.03,0.07,0.11,0.15,0.19$, and $0.22 \mathrm{mg} / \mathrm{ml}$ in $80 \%$ methanol. Then, $100 \mu \mathrm{l}$ of each gallic acid solutions was added to $2.8 \mathrm{~mL}$ of distilled water, $2 \mathrm{ml}$ of $2 \%$ sodium carbonate (Na2CO3) solution and $100 \mu \mathrm{L}$ of $50 \%$ FolinCiocalteu reagent and then tubes were incubated for $30 \mathrm{~min}$. After that, their absorbance was recorded at $720 \mathrm{~nm}$ compared to the control. The calibration curve of gallic acid was prepared using the solution absorbance against concentration.

For determination of the total phenolic content of each extract, it was diluted with $80 \%$ methanol until its absorbance obtains in the range of the prepared calibration curve. Then, $100 \mu \mathrm{l}$ of each diluted extract was added to $2.8 \mathrm{~mL}$ of distilled water, $2 \mathrm{ml}$ of $2 \%$ sodium carbonate $(\mathrm{Na} 2 \mathrm{CO} 3)$ solution and $100 \mu \mathrm{L}$ of $50 \%$ Folin-Ciocalteu reagent and then tubes were incubated for $30 \mathrm{~min}$. After that, their absorbance was recorded at $720 \mathrm{~nm}$ compared to the control. The total phenolic contents of the extracts were reported based on milligrams of gallic acid equivalents per grams of dry weight of plant and extract (mg GAE/g DW) (MEDA ET AL., 2005).

\section{Antioxidant Activity Assays \\ DPPH (2, 2-diphenyl-1-picrylhydrazyl) assay}

In this test, the antioxidant activity was described by 2, 2-diphenyl-1-picryhydrazyl (DPPH) free radical scavenging capacity of the extract based on one-electron reduction [SHARMA 2013, SINGH 2007]. In this method, DPPH solution $(0.004 \% \mathrm{w} / \mathrm{v}$, $0.1 \mathrm{mM}$ ) was prepared in methanol, $3.9 \mathrm{ml}$ of this solution was added to $0.1 \mathrm{ml}$ of sample solution and then incubated at room temperature for $30 \mathrm{~min}$, the absorbance was measured at $517 \mathrm{~nm}$ and the experiment was carried out in triplicate (GOLMAKANI 2014). The percentage of radical scavenging activity was calculated from Equation (1):

Eq (1):

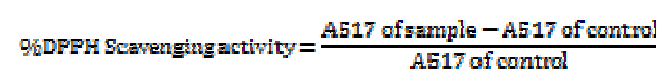

Methanol was used as blank, ascorbic acid and BHT as positive controls.

\section{FRAP Assay}

$100 \mu \mathrm{L}$ of each extract was added to $3 \mathrm{~mL}$ of FRAP reagent $(300 \mathrm{mM}$ sodium acetate buffer $\mathrm{pH} 3.6$, tripyridyl triazine $10 \mathrm{mM}$, and ferric chloride $20 \mathrm{mM}$ ). The mixture was vortexed and incubated at $30^{\circ} \mathrm{C}$ for 4 minutes. The control containing $100 \mu \mathrm{L}$ distilled water with $3 \mathrm{~mL}$ of FRAP reagent. Absorbance of the solutions was read at $593 \mathrm{~nm}$ against control. Aqueous solutions of $\mathrm{FeSO}_{4} \cdot 7 \mathrm{H}_{2} \mathrm{O}$ $(0-1 \mathrm{mM})$ were used for calibration curve. The calibration curve was plotted with absorbance and concentration, and then total antioxidant activity was expressed as mmol $\mathrm{Fe}$ (II)/ g extract (mean \pm standard error) ( $\mathrm{Xu}$ 2010).In this method, the electron donating feature of antioxidants at low $\mathrm{pH}$ leads to reduction of ferric cation to ferrous. Hence, they can convert colorless ferric tripyridyl triazine complex to blue ferrous tripyridyl triazine which absorbs at $593 \mathrm{~nm}$.

\section{$\beta$-carotene Bleaching Assay (BCB)}

Antioxidant activity of Stachys turcomanica for preventing oxidation of linoleic acid was studied through $\beta$-carotene linoleic acid method (KUMAZAWA et al., 2002). In this method, 200 $\mathrm{mg}$ of Tween 20,20 $\mu \mathrm{L}$ of linoleic acid and $1 \mathrm{mg}$ of $\beta$-carotene were added to $5 \mathrm{~mL}$ of chloroform. After that the mixture was put at $40^{\circ} \mathrm{C}$ until the chloroform had evaporated. Then, $50 \mathrm{~mL}$ of distilled water was added to the mixture and it was shacked for $30 \mathrm{~min}$. $50 \mu \mathrm{L}$ of each extract was added to 6 $\mathrm{mL}$ of this mixture. In the control tube, the mixture was added to $50 \mu \mathrm{L}$ of methanol. After that, the absorbance was measured at $470 \mathrm{~nm}\left(\mathrm{~A}_{0}\right)$, and the tubes were placed in a water bath at $50{ }^{\circ} \mathrm{C}$ for $2 \mathrm{~h}$ to catalyze the oxidation reaction and discoloring of $\beta$ carotene. The absorbance of mixtures was measured at $470 \mathrm{~nm}\left(\mathrm{~A}{ }_{120}\right)$ to calculate the decreased absorbance in each sample. All of the analyses were performed in triplicate. BHT was used as positive control. The antioxidant activity index (AAI) was carried out using Equation (2):

$\mathrm{Eq}(2): \quad$ AAI $\%=1-\frac{(A 0-A 120) \text { sample }}{(A 0-A 120) \text { cortrol }} \times 100$

\section{RESULTS AND DISCUSSION}

One of the important steps in optimizing the recovery of antioxidant compounds from a sample is the selection of solvent. In this study, the effect of type of solvent in total phenolic and antioxidant activity was evaluated. The yields of extraction were shown in Table 1. As shown in Table 1, the highest yield extraction was for methanol $80 \%$ with $27.33 \%$ yield and aqueous extract had lowest yield of extraction. In other studies, effects of aqueous and organic solvents in extracting different polyphenols has been reported (WANG ET AL., 2009) and they showed efficiency of water and methanol as extraction solvents. 
In this study, total phenolic compounds of extracts were evaluated and the results were presented in Table (1). Standard curve of Gallic acid was drawn and the regression equation was: $\mathrm{y}=$ $0.009 \mathrm{x}-0.007\left(\mathrm{R}^{2}=0.996\right)$. The maximum phenolic content was found in methanol 50\% extract (17.36 mg GAE /g dried extract). The quantitative determination of phenolic compounds using FolinCiocalteu method is a widespread assay. In this method, the oxidation of phenols in alkaline solution and colorimetric measurement of the blue product was done [TAWAHA 2007].

Table 1. Extraction yield and total phenolic content of various extracts from Stachys turcomanica

\begin{tabular}{cccc}
\hline Extracts & Extraction yield $(\%)$ & \multicolumn{2}{c}{ Total phenolic contents } \\
\cline { 3 - 4 } & & $(\mathrm{mg} \mathrm{GAE} / \mathrm{g}$ extract $)$ & $(\mathrm{mg}$ GAE/kg DW $)$ \\
\hline Methanol 100\% & $21.24 \%$ & $14.263 \pm 1.1$ & \pm 1.13029 .46 \\
Methanol 80\% & $27.33 \%$ & $15.36 \pm 3.5$ & $4197.8 \pm 3.5$ \\
Methanol 50\% & $21.5 \%$ & $17.36 \pm 2.5$ & $3732.6 \pm 2.5$ \\
Methanol 20\% & $20.0 \%$ & $11.90 \pm 1.5$ & $2380.5 \pm 1.5$ \\
Aqueous & $10.37 \%$ & $12.52 \pm 1.7$ & $1299.0 \pm 1.7$
\end{tabular}

${ }^{a}$ Results correspond to the average \pm standard deviation estimated from three aliquots of extracts.

The phenolic compounds donate electrons and delocalize the unpaired electron with their aromatic structures (ROSS, 2002).

In this study, the $80 \%$ methanolic extract was found to contain higher total phenolic content than other extracts. Thus, this solvent is considered as a better and more efficient solvent system for extracting polyphenols.

The use of natural antioxidants can produce few side effects because of their low toxicity compared to other drugs [STÜLP 2012].

Several methods have been used for evaluation of antioxidant activity and each of them has some problems and limitations (DECKER, WARNER, RICHARDS; SHAHIDI, 2005; MAGALHÃES, SEGUNDO, REIS, AND LIMA, 2008).

In this study, antioxidant activity of extracts was evaluated with three methods DPPH, FRAP and $\beta$-carotene Bleaching.

The DPPH method is commonly method because it is simple, efficient and inexpensive. In this method, DPPH is a free radical that shows a maximum absorption at $517 \mathrm{~nm}$ and DPPH scavenging activity is based on the ability of sample to donate hydrogen which reacts with the DPPH radical and a reduction in absorbance was happened [KNEZEVIC 2011, MICHALAK 2006]. The DPPH radical scavenging activity of extracts is dependent on concentration. In this test, the results were reported as $\mathrm{IC}_{50}$, which is defined as the amount of antioxidant can inhibit 50\% of DPPH free radicals. A lower value of $\mathrm{IC}_{50}$ indicates a higher antioxidant activity (HATAMNIA ET AL., 2014).
$\mathrm{IC}_{50}$ values of extract and positive controls were shown in Table 2. In the present study all of extracts had lower antioxidant activities as compared to the standard BHT. Also, the strongest DPPH activity was obtained by $80 \%$ methanolic extract and lowest activity was obtained in $20 \%$ methanolic extract. In Figure 1, the effects of solvent extraction on inhibition of free radicals were shown. In the FRAP assay, the ferric reducing ability was measured and the antioxidant activities were expressed by the reduction of ferric tripyridyltriazine complex to form a blue color ferrous tripyridyltriazine complex [EBRAHIMZADEH 2010]. In FRAP assay, The Equation for standard solution was: $\mathrm{y}=0.380 \mathrm{x}+$ $0.020\left(\mathrm{R}^{2}=0.989\right)$. In the present study, the FRAP value expressed in Table 2 . The results showed methanol $80 \%$ extract revealed the highest ferric reducing potential.

Table 2 shows the antioxidant capacity of extracts using the beta-carotene/linoleic acid. The range for all extracts was 11-35\% inhibition. This shows that there are different amounts of antioxidants in various extracts. The results showed methanol $80 \%$ with $35.85 \%$ inhibition had highest antioxidant activity in this method. In this study, with increasing water content in the solvent, yield, total phenolic contents and antioxidant activities were decreased. The results showed the total phenolic content and antioxidant activity decreased with increasing water solvent in extracting solvent because the water extract contain more non phenolic compounds or possess phenolic compounds that contain a smaller number of active groups than the other solvents. 


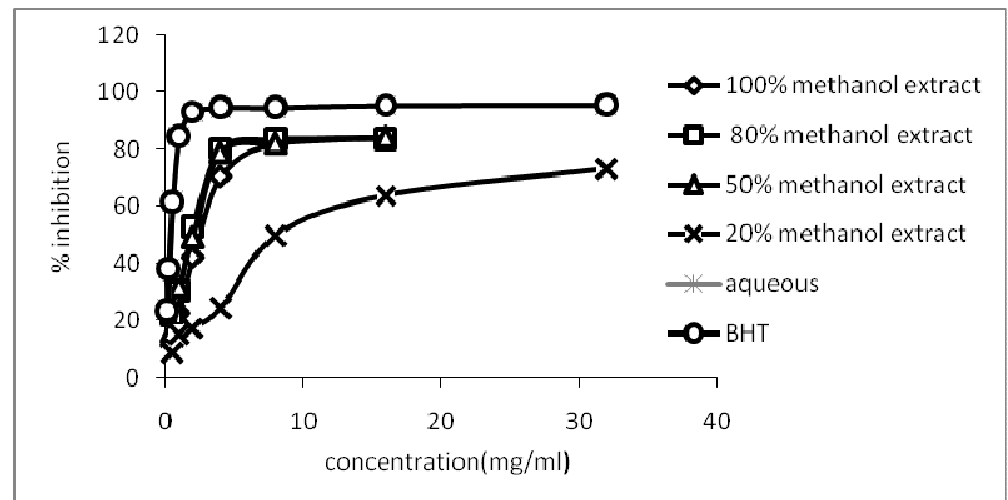

Figure 1. DPPH (2, 2-diphenyl-1-picrylhydrazyl) radical scavenging activity of Stachys turcomanica extracts in different solvents.

Table 2. Antioxidant activity of various extracts of Stachys turcomanica using the DPPH, FRAP and bcarotene/linoleate model systems.

\begin{tabular}{cccc}
\hline Extracts & $\mathrm{IC}_{50}(\mathrm{mg} / \mathrm{mL})$ & $\begin{array}{c}\text { FRAP value (mmolFe2+/g dry } \\
\text { extract) }\end{array}$ & $\begin{array}{c}\text { Carotene-linoleate }(\% \\
\text { inhibition) }\end{array}$ \\
\hline Methanol 100\% & 2.58 & 1240 & $28.59 \pm 0.51$ \\
Methanol 80\% & 1.71 & 1330 & $35.85 \pm 0.19$ \\
Methanol 50\% & 1.87 & 1260 & $33.9 \pm 2.85$ \\
Methanol 20\% & 9.93 & 680 & $11.18 \pm 0.15$ \\
Aqueous & 6.98 & 960 & $29.6 \pm 0.46$ \\
BHT & 0.125 & --- & $93.25 \pm 0.09$ \\
\hline
\end{tabular}

Significant positive relationships were obtained between total phenolic content and the antioxidant activities evaluated by DPPH, FRAP, beta-caroten linoleic acid assays $(0.768,0.692$ and
0.550 respectively). The correlation coefficients between the inhibition of DPPH (IC50) and total phenolic showed strong but negative relationships (Figure 2)..

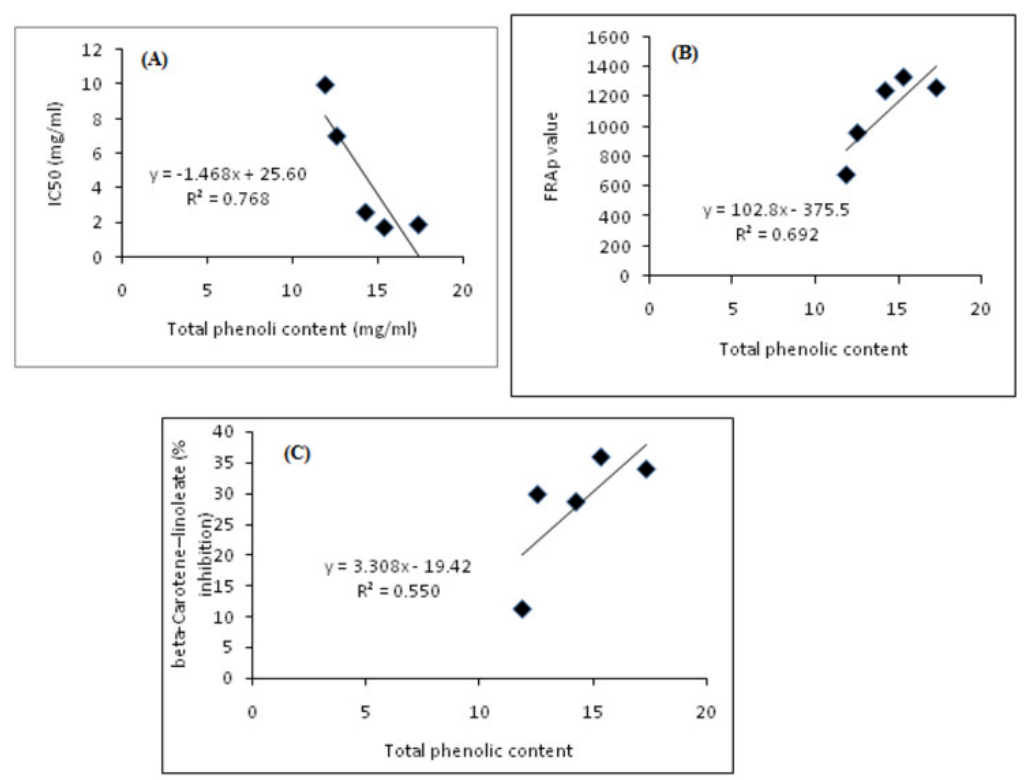

Figure 2. Correlation of total phenolic content and antioxidant activity via three method assays 
Total phenolic compounds...

The results showed stronger correlation between total phenolic content and antioxidant activities, thus in this study, potent contribution of phenolic compounds to the antioxidant capacities of Stachys turcomanica was shown (BENMEDDOUR, MEHINAGIC, MEURLAY; LOUAILECHE, 2013). Also these results showed, the beta-caroten linoleic acid method was the least correlated with total phenolic content compared to FRAP and DPPH methods, while all showed a good correlation. This may be due the methods of total phenolic content by Folin-Ciocalteu reagent, FRAP and DPPH methods which involve electron transfer reaction mechanism. In other studies this correlation was shown (PAJA_K.; SOCHA; GAŁKOWSKA; RO_ZNOWSKI; FORTUNA, 2014).

\section{CONCLUSIONS}

The extraction of phenolic compounds and their antioxidant capacity is affected by solvent combinations.

There was a good correlation between total phenolic content and the antioxidant capacity of the Stachys turcomanica extracts.

The methanol: water $(80: 20)$ extract was good solvent in extracting of phenolic compounds with highest antioxidant activity. These results demonstrated this extract was the best solvent to release of most secondary metabolites from Stachys turcomanica for future studies, which could provide natural sources of antioxidant compounds.

RESUMO: O tema dos radicais livres e seus efeitos nos sistemas biológicos é um problema importante na medicina. Os antioxidantes podem proteger os sistemas biológicos contra os radicais livres. Neste estudo, avaliou-se o efeito da proporção de metanol $(0,20,50,80$ e 100\%) na água com o rendimento de extração de compostos fenólicos totais (TP) e atividade antioxidante (AA) do extrato Stachys turcomanica. A quantidade de compostos de TP foi determinada utilizando o reagente de Folin-Ciocalteu, e AA medido por 2, 2-difenil-1-picrilidrazilo (DPPH), poder antioxidante redutor férrico (FRAP) e ácido beta-caroten ácido linoleico. Os resultados mostraram a extração de compostos fenólicos e os seus AA foram afetados por combinações de solventes. Além disso, houve uma boa correlação entre o conteúdo de TP e os extratos de AA de Stachys turcomanica. Finalmente, o metanol: água (80:20) foi bom solvente na extração de compostos fenólicos com AA mais alto.

PALAVRAS-CHAVE: Atividade antioxidante. Compostos fenólicos. Stachys turcomanica.

\section{REFERENCES}

AGHAEI Y; MIRJALILI, H. M.; NAZERI, V. Chemical diversity among the essential oils of wild populations of Stachys lavandulifolia VAHL (Lamiaceae) from Iran. Chem Biodivers, v. 10, p. 262-273. https://doi.org/10.1002/cbdv.201200194

AYDIN A, SENER B.; CAKICI, I.; TURAN, N. N.; ERDEMOGLU, N. Antioxidant activities of some Lamiaceae plant extracts. Phytother Res. v. 20, p. 91-93.

BURDA, S.; OLESZEK, W. Antioxidant and antiradical activities of flavonoids. J. Agric. Food. Chem., v. 49, n. 6, p. 2774-2779. https://doi.org/10.1021/jf001413m

BENMEDDOUR, Z.; MEHINAGIC, E.; MEURLAY, D. L.; LOUAILECHE, H. Phenolic Composition and Antioxidant Capacities of Ten Algerian Date (Phoenix dactylifera L.) Cultivars: A Comparative Study. J Funct Foods, v. 5, p. 346-354. https://doi.org/10.1016/j.jff.2012.11.005

DELAZAR, A.; DELNAVAZI, M. R.; NAHAR, L.; MOGHADAM, S. B.; MOJARAB, M.; GUPTA, A.; WILLIAMS, A. S.; RAHMAN, M. M.; SARKER, S. D. Lavandulifolioside B: a new phenylethanoid glycoside from the aerial parts of Stachys lavandulifolia Vahl. Nat Prod Res., v. 25, p. 8-16. https://doi.org/10.1080/14786411003754330

DIGRAK, M.; HAKKI ALMAM; ILCIM, A. Antibacterial and antifungal activities of Turkish medicinal plants Pharm Biol. v. 39, p. 346-50. https://doi.org/10.1076/phbi.39.5.346.5903 
DECKER, E. A.; WARNER, K.; RICHARDS, M. P.; SHAHIDI, F. Measuring antioxidant effectiveness in food. J Agric Food Chem. v. 53, p. 4303-4310. https://doi.org/10.1021/jf058012x

EL-ANSARI M.A; NAWWAR M.A; SALEH N.A. M. Stachysetin, a diapigenine-7-glucoside-p-p_dihydroxy-truxinate from Stachys Aegyptiaca. Phytochem. v. 40, p. 1543-1548. https://doi.org/10.1016/00319422(95)00395-N

EBRAHIMZADEH M. A.; NABAVI S.M.; NABAVI S. F.; BAHRAMIAN F.; BEKHRADNIA A.R. Antioxidant and free radical scavenging activity of $\mathrm{H}$. officinalis, Var. angustifolius, V. odorata, B. hyrcana and C. speciosum. Pak J Pharm Sci. v. 23, n. 1, p. 29-34.

GHAHRAMAN A. Color Atlas of Iranian Flora. Tehran: Research Institute of Forests and Rangelands Publishing, v. 18, 738.

GRUENWALD J, BRENDLERT, JAENICKE C (2000). PDR for herbal medicine. Medicine economic Company, 2nd, 832, Montvale, New Jersey.

GOLMAKANI E.; MOHAMMADI A.; AHMADZADEH SANI T.; KAMALI H. (2014). Phenolic and flavonoid content and antioxidants capacity ofpressurized liquid extraction and perculation method from roots of Scutellaria pinnatifida A. Hamilt. subsp alpina (Bornm) Rech. f. J Supercrit Fluids, v. 95, p. 318-324. https://doi.org/10.1016/j.supflu.2014.09.020

HAJHASHEMI V, GHANNADI A, SEDIGHIFAR S (2007). Analgesic and anti-inflammatory properties of the hydroalcoholic, polyphenolic and boiled extracts of Stachys lavandulifolia. Res Pharm Sci., v. 2, p. 92- 98.

HOLLMAN P.C.H.; HERTOG M.G.L.; KATAN M.B. Analysis and health effects of flavonoids. Food Chem., v. 57, n. 1), p. 43-46. https://doi.org/10.1016/0308-8146(96)00065-9

HATAMNIA A. A.; ABBASPOUR N.; DARVISHZADEH R. Antioxidant activity and phenolic profile of different parts of Bene (Pistacia atlantica subsp. kurdica) fruits. Food Chem., v. 145, p. 306-311.

https://doi.org/10.1016/j.foodchem.2013.08.031

KUMAZAWA S.; TANIGUCHI M.; SUZUKI Y.; SHIMURA M.; KWON M.; NAKAYAMA T. Antioxidant Activity of Polyphenols in Carob Pods. Agric. Food Chem., v. 50, p. 373- 377.

https://doi.org/10.1021/jf010938r

KNEZEVIC S.V, BLAZEKOVIC B, STEFAN M.B, ALEGRO A, KOSZEGI T, PETRIK J (2011).

Antioxidant activities and polyphenolic contents of three selected Micromeria species from Croatia, Molecules, v. 16, p. 1454-70. https://doi.org/10.3390/molecules 16021454

LIYANA-PATHIRANA C, SHAHIDI F (2005). Optimization of extraction of phenolic compounds from wheat using response surface methodology. Food Chem., v. 93, n. 1, p. 47-56.

https://doi.org/10.1016/j.foodchem.2004.08.050

MEDA A.; LAMIEN C. E.; ROMITO M.; MILLOGO J.; NACOULMA O. G. Determination of the Total Phenolic, Flavonoid and Pralin Contents in Burkina Fasan Honey, as well as Their Scavenging Activity. Food Chem., v. 91, p. 571-577. https://doi.org/10.1016/j.foodchem.2004.10.006

MICHALAK A. Phenolic compounds and their antioxidant activity in plants growing under heavy metal stress, Polish J Env Stud., v. 15, p. 523-30.

MIYASE T, YAMAMOTO R, UENO A (1996). Phenyl ethanoid glycosides from Stachys officinalis. Phytochem., v. 43, p. 475-479. https://doi.org/10.1016/0031-9422(96)00322-6 
MALEKI N.; GARJANI A.; NAZEMIYAH H.; NILFOUROUSHAN N.; EFTEKHAR SADAT AT.;

ALLAMEH Z.; HASANNIA N. Potent anti-inflammatory activities of hydroalcoholic extract from aerial parts of Stachys inflate on rats. J Ethnopharmacol., v. 75, p. 213-218. https://doi.org/10.1016/S03788741(01)00194-5

MAGALHÃES L.M.; SEGUNDO M.A.; REIS S.; LIMA J.L. Methodological aspects about in vitro evaluation of antioxidant properties. Anal Chim Acta, 14; v. 613, n. 1, p. 1-19.

MOZAFFARIAN V. A Dictionary of Iranian Plant Names. Farhang Moaser, Tehran, Iran, p. 522.

NOBRE C.P, RAFFIN F.N, MOURA T.F (2005). Standardization of extracts from Momordica charantia L. (Cucurbitaceae) by total flavonoids content determination. Acta Farm Bonaerense. 24(4): 526-566.

NISHIMURA H, SASAKI H, INAGAKI N, CHIN M, MITSUHASHI H. Nine phenethyl alcohol glycosides from Stachys seiboldii. Phytochem., v. 30, p. 9659-9669. https://doi.org/10.1016/0031-9422(91)85288-B

PRACHAYASITTIKUL S, BURAPARUANGSANG P, WORACHARTCHEEWAN A, ISARANKURA-NAAYUDHYA C, RUCHIRAWAT S, PRACHAYASITTIKUL V (2008). Antimicrobial and antioxidative activities of bioactive constituents from Hydnophytum formicarum Jack. Molecules, v. 13, p. 904-21. https://doi.org/10.3390/molecules13040904

PAJAK P.; SOCHA R.; GAŁKOWSKA D.; ROZNOWSKI J.; FORTUNA T. Phenolic profile and antioxidant activity in selected seeds and sprouts. Food Chem., p. 143, p. 300-306.

https://doi.org/10.1016/j.foodchem.2013.07.064

RABBANI M, SAJJADI S. E, JALALI A. Hydroalcohol extract and fractions of Stachys lavandulifolia Vahl: effects on spontaneous motor activity and elevated plus-maze behavior. Phytother Res., v. 19, p. 854-858. https://doi.org/10.1002/ptr.1701

RABBANI M, SAJJADI S. E, ZAREI H. R. Anxiolytic effects of Stachys lavandulifolia Vahl on the elevated plus-maze model of anxiety in mice, J Ethnopharmacol., v. 89, p. 271-276.

https://doi.org/10.1016/j.jep.2003.09.008

RECHINGER KH, HEDGE IC. Flora Iranica. Akademisch Druck-und Verlagsanstalt, Graz, Austria 150: 360361.

ROSS J.A, KASUM C.M. Dietary flavonoids: bioavailability, metabolic effects, and safety, Ann Rev Nutr., v. 22, p. 19-34. https://doi.org/10.1146/annurev.nutr.22.111401.144957

SHARMA V, SINGH, M. Enumerating the antioxidant potential and in vitro radical scavenging activity of the ethanolic root extract of operculina turpethum. World journal of pharmacy and pharmaceutical science, v. 2, p. $2850-2860$.

SEMNANI K. M, SAEEDI M, SHAHANI S (2006). Antioxidant activity of the methanolic extracts of some species of Phlomis and Stachys on sunflower oil, Afr J Biotech., v. 5, p. 2428-2432.

SINGH R, SINGH S, KUMAR S, ARORA S. Evaluation of antioxidant potential of ethyl acetate extract/fractions of Acacia auriculiformis A. Cunn. Food Chem Toxicol., v. 45, p. 1216-23.

https://doi.org/10.1016/j.fct.2007.01.002

STÜLP M, CLEMENTE E, OLIVEIRA D.M, GNAS B.B.B. Conservaço e qualidade de 533 mirtilo orgânico utilizando revestimento comestẹvel a base de fécula de 534 mandioca, Rev Bras De Tecnol Agroindustr., v. 6, p. 713-721. 
THABREW M.I, HUGHES R.D, MCFARLANE I.G. (1998). Antioxidant activity of Osbeckia aspera. Phytother Res., v. 12, p. 288-290. https://doi.org/10.1002/(SICI)1099-1573(199806)12:4<288::AIDPTR228>3.0.CO;2-6

TUNDIS R, PERUZZI L, MENICHINI F. Phytochemical and biological studies of Stachys species in relation to chemotaxonomy: a review. Phytochem, v. 102, p. 7-39. https://doi.org/10.1016/j.phytochem.2014.01.023

TAWAHA K, ALALI F, GHARAIBEH M, MOHAMMAD M. Antioxidant activity and total phenolic content of selected Jordanian plant species. Food Chem, v. 104, p. 1372-1378.

https://doi.org/10.1016/j.foodchem.2007.01.064

VELIOGLU Y.S.; MAZZA G, GAO L, OOMAH B.D. Antioxidant activity and total phenolics in selected fruits, vegetables, and grain products. J Agri Food Chem, p. 46, p. 4113-4117.

https://doi.org/10.1021/jf9801973

WANG, Z.; HSU, C.; YIN, M. Antioxidative characteristics of aqueous and ethanol extracts of glossy privet fruit. Food Chem, v. 112, n. 4, p. 914-918. https://doi.org/10.1016/j.foodchem.2008.06.078

XU, X.; XIE, H.; WANG, Y.; WEI, X. A-type proanthocyanidins from lychee seeds and their antioxidant and antiviral activities. J Agri Food Chem, v. 58, p. 11667-11672. https://doi.org/10.1021/jf1033202 